\title{
From Forestry Machines to Sociotechnical Hybrids: Investigating the Use of Digitally Enabled Forestry Machines
}

\author{
Daniel Nylén and Jonny Holmström \\ Umeå University, Department of Informatics, 90187 Umeå, Sweden \\ \{daniel.nylen, jonny.holmstrom\} @informatik. umu.se
}

\begin{abstract}
Most forestry machines being produced today include a personal computer that monitors and controls the harvester head, and an information system that stores data on every action the driver or the machine performs. Information and communication technologies (ICTs) thus provide an opportunity to improve efficiency and competitiveness and possibly also opens up new ways of working for actors in the forestry industry. The purpose of this study is to investigate how ICT can enable the transformation from selling products to selling services in the forestry industry. We investigate such transformation through conducting a case study including a number of actors from the forestry industry in northern Sweden. First, we investigate the barriers for establishing an open innovation system in forestry. Then we describe how the use of ICTs can enable the establishment of such a system. The case study shows that the forestry industry as a whole is dominated by the salient traditional value chain where the raw materials are refined to paper products and that many of the actors are committed to a closed innovation paradigm. We argue that the ICT component in forestry machines constitutes a latent potential that can be fully captured in the context of an open innovation system.
\end{abstract}

Keywords: Open innovation, value constellations, materiality, forestry industry.

\section{Introduction}

Information and communication technologies (ICTs) enjoy a pervasive role in most societal contexts. In the past few decades, ICTs have come to play a major role in traditional industry settings (Jonsson et al. 2008; Holmström et al. 2010; Zuboff 1988). The forestry industry is no exception as it has become a high-tech industry in recent years. The mechanization of forestry in Sweden started in the 1960s, when woodsmen using chainsaws and log-driving and transports by horse were gradually replaced by tractors and lorries. During this decade, productivity increased drastically while the number of forestry workers was reduced by half. The first fully mechanical forestry machines were imported from Canada, the United States, and Russia and, in 1970 , six percent of the timber was logged with forestry machines. This figure grew 
during that decade and was as high as 65 percent by 1980. During the 1990s, production was transformed from being of a bulk-character to being customeroriented.

Continuous technical development has resulted in the harvesters and forwarders of today. Most machines today include a personal computer that monitors and controls the harvester head (the device in which the chainsaw is mounted) and an information system that stores data on almost every action the driver or the machine performs. ICT thus provides an opportunity to improve efficiency and competetiveness, and possibly opportunities for new ways of working. To this end, the use of ICTs in the forestry industry reflects patterns of usage found in other settings where ICTs have enabled the transformation of organizational collaboration (Holmström and Boudreau 2006; Leonardi 2009; Leonardi and Barley 2010), the transformation of business models (Jonsson et al. 2008), or flattening of organizational hierarchies to an open innovation ideal (Westergren and Holmström 2008).

While previous research has emphasized the mediating role of ICTs across multiple organizational contexts (Boudreau and Robey 2005; Rolland and Monteiro 2002), few empirical studies have demonstrated how ICT establish links between previously independent contexts (Vaast and Walsham 2009), thereby allowing for more distributed work practices (Pollock et al. 2009). Our study is inspired by these recent accounts, yet our empirical and analytical basis is different. The purpose of this study is to investigate how ICTs can enable the transformation from selling products to selling services in the forestry industry. Given the ways in which firms in the forestry industry are embedded in a wider innovation system, the analysis is guided by the following research question: How can the use of ICTs enable the establishment of open innovation systems in the forestry industry?

We use the open innovation lens in pursuing the research question. In the open innovation paradigm, firms do not try to protect their innovation processes to the same extent as in the closed innovation paradigm. Firms bring in knowledge from the research of other firms and share their own knowledge with other firms. This can be done through joint ventures, spin-ins, and spin-offs. This way of doing business often requires new business models aid in making sure that the firm captures some of the value it helped to create (Chesbrough 2006). The literature on open innovation is particularly silent on the role of ICTs in open innovation settings. To this end, we seek to contribute to this domain by paying close attention to the role of ICT in the transformation processes in forestry, and how a heterogeneous set of actors-human as well as nonhuman-forming sociotechnical hybrids (see Jonsson et al. 2009).

\section{Related Research}

We begin by outlining existing research on open innovation models. Building on how firms in the forestry industry are embedded in a wider innovation system, we proceed to present existing research on materiality, enabling us to be specific about the role of IT in open innovation contexts.

\subsection{Open Innovation}

The term open innovation was first coined by Henry Chesbrough. In the closed innovation model, the $R \& D$ staff develops products that might eventually reach the 
market-sold and distributed by the firm (Chesbrough 2006). What characterizes the open innovation paradigm, in contrast, is that firms do not try to protect their research to the same extent. Companies bring in knowledge from the research of other firms and share their own knowledge with other firms. Each firm will, of course, want to claim a certain amount of value from a given innovation, but it is not necessary that the innovation reaches the market through the internal path. Chesbrough (2006, p. 2) defines open innovation as

the use of purposive inflows and outflows of knowledge to accelerate internal innovation, and expand the markets for external use of innovation, respecttively. Open innovation is a paradigm that assumes that firms can and should use external ideas as well as internal ideas, and internal and external paths to market, as the firms look to advance their technology.

The research on how to organize for open innovation is still very limited (Fredberg et al. 2008). Vanhaverbeke (2006) stresses the need to address a broader scope of analysis and argues that open innovation should be analyzed not only at the firm level, but also on the dyad-, intra-organizational, and interorganizational levels (Vanhaverbeke 2006).

In their 2002 article, Chesbrough and Rosenbloom set out to answer the question: Why do successful companies often fail to capture value from new technology that they helped to create? According to Chesbrough and Rosenbloom, there are two ways that firms can capture value from new technology:

1. Through incorporating the technology in their current businesses

2. Through launching new ventures that exploit the technology in new business arenas

The fundamental starting point for Chesbrough and Rosenbloom's theories is that a certain technology may have an inherent value, but it remains latent until it is enacted in some way. The value network created around the firm determines the role that suppliers, customers, and third parties play in influencing the value captured from the enactment of an innovation (Chesbrough and Rosenbloom 2002). The actors in the value-creating system produce value together through rethinking their roles and interrelationships. Hence, value creation is not just adding value step after step but reinventing it by means of a reconfiguration of the roles and relationships among actors of the value creating system (Vanhaverbeke and Cloodt 2006). In sum, value creation in constellations is determined by (Vanhaverbeke and Cloodt, 2006):

1. The resources it assembles

2. The way it can combine and govern those resources

3. The value of competing products and the competitive reactions of competing firms and constellations

Fair value distribution in a value constellation is important; it is crucial that all participants profit from their participation. Some actors are automatically better off in the new constellation compared to the old value creating system. Others might be worse off and have to be compensated to stay committed to the value constellation (Vanhaverbeke and Cloodt 2006). 


\subsection{Materiality}

The open innovation literature is largely silent on the role of ICTs in an open innovation environment. This is perhaps not surprising; IS researchers have only recently started to conceptualize how ICTs influence multiple and previously independent work practices. In their study of how a packaged software producer provides customer support, Pollock et al. (2009) illustrate how new ICTs allowed the move to technical repairs online. In a similar vein, we believe that ICTs hold the potential to enable the establishment of open innovation systems in the forestry industry.

The focus in extant research on IT-enabled change is on changes caused by increased digitization, reflecting of the more general trend within information systems research to treat IT as a "black box," disregarding which IT attributes are used and how they are used (Orlikowski and Iacono 2001). To address this limitation, IS scholars have recently begun to pay attention to materiality issues associated with IT (Leonardi and Barley 2010; Orlikowski and Scott 2008; Zammuto et al. 2007).

Orlikowski (2007) has argued that even though new digital artifacts play a ubiquitous role in contemporary organizations, research "largely disregards, downplays, or takes for granted the materiality of organizations." She argues that "material artifacts" must be better addressed in management studies to show how they are fundamentally transformed by social practices and, subsequently, transform them:

Consider any organizational practice, and then consider what role, if any, materiality may play in it. It should be quickly evident that a considerable amount of materiality is entailed in every aspect of organizing, from the visible forms-such as bodies, clothes, rooms, desks, chairs, tables, buildings, vehicles, phones, computers, books, documents, pens, and utensils-to the less visible flows-such as data and voice networks, water and sewage infrastructures, electricity, and air systems (Orlikowski 2007, p. 1436).

Discussing the physical and nonphysical matter of IT, Leonardi (2007, p. 816) notes how "the impact of its material features is transformed through the social action of collective appropriation." For example, as people confront a specific IT (human agency) that does specific things that are not completely in their control (material agency), they contend with the material agency of the technology and find ways to maneuver around it. Indeed, material agency comes in many forms and shapes and the material agency associated with IT is, for these reasons, fundamentally different from that associated with other artifacts. To this end, we need to be specific about IT while also being specific about the ways in which IT is implicated with social practices.

\section{Research Methodology}

This paper reports on an interpretive case study based on interviews with actors from the forestry industry in northern Sweden. The case study is single case, involving multiple firms. The case study approach was chosen due to its strengths in providing a way of collecting data and analyzing a contemporary phenomenon (Yin 2003).

The case study aimed at gaining an understanding for how work is organized in the forestry industry, which roles the different actors play, and how they are interrelated. 
The actors studied are mainly located in one county. A total of 11 organizations were selected for participating in the case study (see the Appendix).

Data were collected in two phases. In the first phase, four interviews were conducted. The aim was to explore how work is organized in the forestry industry in northern Sweden. The authors needed to gain an understanding for the context and to start identifying key actors. To achieve this, interviews in this phase were of an open and unstructured character. After the first round of interviews the data were analyzed. The analysis provided a deeper understanding of the phenomenon and served as input for the next round of interviews. An interview guide was created based on these insights. Nine semi-structured interviews were conducted in the second phase.

Most of the interviews were conducted in offices and meeting rooms at the client's premises. The exceptions were two interviews conducted by telephone. In both phases, the duration of the interviews varied from 50 minutes to 1 hour, 45 minutes. The interviews were digitally recorded and later transcribed. An iterative process commenced, where the transcriptions were read several times. Emerging patterns were identified and coded with an open-ended approach, allowing grouping into themes. These themes built the foundation for the results and analysis presented in the paper.

When writing up the results and analysis sections, our ambition was to tell the story in its diversity, rather than summing up (Flyvbjerg 2006). All informant and firm names have been fictionalized in order to protect and respect privacy. Ultimately an interpretive case study seeks to contribute to theorizing (Holmström 2005; Truex et al. 2006; Walsham 1995), which in this particular case is focused on contributing back to the extant research on IT-enabled change. As outlined by Truex et al. (2006), an ambitious research program will also seek to contribute back to the "mother discipline" from which the analytical lens is borrowed. In this case, we will make an effort to contribute back to open innovation.

\section{Case Study}

We now present the data collected through interviews with a number of actors from the forestry industry in northern Sweden. In what follows, we will present the forestry machine supply chain, its key actors, and how the ICT component in the logging process holds the potential for radically restructuring the supply chain.

\subsection{Forestry in Northern Sweden}

Forestry has historically employed a large number of people in northern Sweden. As the mechanization of forestry began in the 1960s, firms producing vehicles and machines to be used were also founded in the area. Timbercut and one of its suppliers was founded in the 1960s. More start-up firms soon followed. Since then, Timbercut has gone through a number of changes in ownership as well as a number of name changes. In 2003, the firm was acquired by a large multinational enterprise. Today, Timbercut is one of the largest forestry machine manufacturers in the world. The headquarters are still located in the northern Swedish town were the original firm was founded. The site contains one of two worldwide manufacturing plants as well as the 
research and development $(\mathrm{R} \& \mathrm{D})$ department. Among the products produced are harvester and forwarder machines.

\subsection{Forestry Machines Supply Chain}

Timbercut's customers exist on a global market. Apart from their Swedish customers, most machines are sold to customers in Brazil, Canada, Finland, and Great Britain. As forestry is organized in varying ways in different countries, the customers are a heterogeneous set of actors. In northern Sweden, however, Timbercut's customers are either logging contractors or forest owning companies. The firms range from a single person owning one machine to large forest-owning companies owning several hundred machines that are operated by as many employees.

As Timbercut has expanded its operations in the area over the last five decades, firms supplying them with components have not only remained in the area, but expanded their operations as well. Supplying firms S1, S2, and S3 are all located in the same county as Timbercut.

Our interviews with Timbercut and its suppliers (S1, S2, and S3) illustrate a tightly knit community. Many of the managers have moved between at least two of the firms. The CEOs at Timbercut, S1, and S2 all know each other through having worked together. The chairman at S1 was hired by the firm in the 1970s. Since then, he has had a long career in different firms around the world, including Timbercut, before coming back to $\mathrm{S} 1$ through acquiring shares and becoming the chairman. Today, S1 and Timbercut still closely collaborate on the product development of their component.

We hire S1 as contract manufacturers of certain components...they are subcontractors to us...Those components are our design....but S1 are a subcontractor-[they] draw on or they build from our drawings...S3, I do not think is a supplier of anything so far. We do not really have cooperation with S3. They are pretty closely linked to the other big forestry machines manufacturer instead. So that's a bit trickier....Yeah, that's when they are suppliers to other brands of machines that they have to try being a bit cautious. Of course, they don't want to jeopardize their relationships with them. S2 don't want to come to us and say, hey, now you should...do this and like this. They have to be a little cautious. [TPM/Timbercut]

The connections between the firms are many, as in fact suppliers S1 and S2 also collaborate with each other.

And with S2, they have their product and we buy it and of course...they are a supplier to us on that product and we do some welding work for them. We have close cooperation. [CEO/S1]

$\mathrm{S} 3$ is also located in the area, but delivers components to the all of the major forestry machines manufacturers apart from Timbercut. The CEO shares his thoughts on where in the supply chain innovation takes place and whose needs S3 should satisfy. 
But they [the forestry machines manufacturers] are the ones controlling what the machine should look like. It's their machine, their brand, their marketing, and so on and so forth. So being an inventor but not being able to determine what the machine should look like, it's a bit of a tricky position. We can be sitting on a bunch of great ideas as we go knocking on their door. They will say, sure, that's interesting, but we do not want to change ours, we have already invested in this production line. [CEO/S3]

He also shares his thoughts on the role of the logging contractors.

The contractors who use the machines are weak. I mean, they are very weak. It is small family businesses, often with huge financial difficulties. So, therefore, we have to work with the one's who, in the end, actually pay. And that's the forest owning companies. [CEO/S1]

\subsection{The Logging Process}

Today, the logging process is close to being completely automated. Like most machines today, Northlog's harvester machine includes a PC that monitors and controls the harvester head. It also contains an information system that picks up data from sensors located on the harvester and forwarder heads. The data covers the length, dimensions and quality of the trees that are logged. This data is fed into software installed on the PC that is mounted on every machine. The PC stores data on almost every action the driver or the machine performs. Although some manual quality controls are performed, the main focus of the driver is operating the machine and monitoring the process.

For the contractor to be able to run a well-functioning organization, the computers in the forestry machines have to be in a serviceable condition at all times. When they are not, it is practically impossible to get any work done.

Yes, it really has accelerated. Nowadays the situation is that if something breaks, for example the computer in the harvester machine, then that's it! We're at a total standstill, since we can't log at all. Everything is totally dependent on computer activity in the machine. It has to work, otherwise you can't use the machine...At best you can move it from its location. [Owner/Logging contractor]

The rural areas of northern Sweden are sparsely populated. Distances between the towns are far. For the logging contractor, this means that the nearest service technician is still 55 kilometers away.

This local guy will come out and help us....He connects a PC laptop to the machine. He has software that we don't have access to. That's because, you know, everyone can't be allowed to play around with that. I mean, you can cause major disorder if you open up files and you don't know what you're doing. The machine will be unusable, it can even nearly become dangerous. [Owner/Logging contractor]

When preparing for the logging of a new area, Northlog receives an apt-file from the customer. The apt-file specifies the length and diameter that is required by the 
sawing mills. The file also controls how the harvester cuts, calculates price, and detects the optimal length for a certain dimension. When the logging activities operate at normal conditions, timber is logged and forwarded to a landing point. A carrier continually picks up the timber at the landing point. The communication between the driver of the harvester machine and the lorry driver is mainly done through mobile phones and com radio.

At the end of each night shift, logging statistics are sent to the Skogsbrukets Datacentral (SDC) server. The data is transferred through a Mobitex system. The Mobitex device is connected to the PC in the harvester machine. A prd-file (production file) is saved on the PC and transferred to the Mobitex device. The data contains information about the timber harvested during the day, amounts of timber located on the clear-cut area, and amounts of timber that have been conveyed to the road.

But then of course we have a Mobitex system. And it is an old technology really...I guess you could discuss that back and forth, but it is a functioning technology. And it has coverage everywhere...They're trying NMT now and they think it seems to work fine, but I have said that the question [is] whether you should jump on every technology step....Well, I guess that I'm thinking along the lines that in this technological march that is going on, maybe there are some steps you probably have to sit out and keep the old technology for a while. [Owner/Logging contractor]

The product manager (TPM) is aware of the fact that there are still logging contractors out there using Mobitex. He recognizes its advantage of providing full coverage in remote forest areas in the inland of northern Sweden where the customers are often located. However, he points out that

It is at a lousy transmission rate, so you can only send short text messages. And you can't use it at all for remote desktop or to send e-mails, browse the web-it is in fact worthless. [TPM/Timbercut]

At Alpha Forest Corp., the logging manager (TLM) is responsible for making sure that the amount of timber logged corresponds to the amount that is supposed to be delivered to a number of saw mills and pulp mills each month. The teams report the volumes logged and forwarded to the landing to TLM on a daily basis. The volumes are then reported to SDC's server. TLM can download the files containing this data from SDC's system and transfer them to her system. These files help her to maintain control over where recently logged timber is located at the moment. She can also get an overview of the amount of timber in the forest warehouse and in the road warehouse.

The logging teams all have access to the web-based information system mapleweb, developed by Alpha. The teams can log-on to mapleweb from home. In the system, a time line visualizes the objects they are to log during the coming month. TLM has estimated the time consumption based on how many cubic meters of forest should be logged in each area and the average performance of the logging team in that type of forest.

The logging team can download information about each object from mapleweb. One of the things they download is the logging directive which contains all of the 
information about the type of forest in the area, etc. They can also download map files from mapleweb. This is done continuously and as soon as the logging team has finished logging an object, they log on to mapleweb from home and download all the information they need to move on and start working with the next object. In practice, the movement from one object to the next often does not happen according to the time line. TLM points out that the deliveries required by the mills often change. This means that she has to reschedule and change the order of the objects on the time line.

When logging has taken place, the timber stays approximately five to six weeks at the landing before it is transported to the mills by the carriers. According to TLM, she can at any time log on to her systems and see how much timber is in the road stock and the forest stock. This information is based on the reports that are uploaded from the harvester and the forwarder.

\subsection{Knowledge and Capabilities}

As the logging process has become automated and partly digitalized, the capability requirements of the drivers have changed. A key competency required of the driver is to be able to assess the terrain and have a high level of driving technique. The driver also needs knowledge of basic forestry such as assessing damage on the stem, skewness, and so forth. Apart from these skills, the driver of today also needs to have skills in computer and mechanical engineering. The driver needs to able to remove, change, and repair files when the computers are not working properly. On mechanical matters, the driver needs to be able to do trouble shooting, basic problem solving, and service on the mechanical parts of the machine. According to the contractor, there are, unfortunately, a lot of drivers that have a negative attitude toward the increased computerization. When asking the contractor which training he prefers the people he hires to have completed, his answer is no such formal training really exists. He acknowledges that there are forestry schools, but his goal when recruiting is to find a full-fledged driver that doesn't have an effect on the overall productivity. According to the contractor, however, they are few and far between. He also concludes that he doesn't really believe that any training program can produce a fully qualified professional.

\subsection{Digitally Enabled Vehicles}

The 1960s and 1970s saw the establishment of forestry machine manufacturers and mechanical suppliers in northern Sweden. In the first decade of the new millennium, as forestry machines started becoming increasingly digitalized, actors focused on ICT emerged and got involved in forestry.

\subsubsection{Digital Services}

Timbercut's core business is currently in selling forestry machines. Apart from selling entire machines, they sell spare parts. The services they offer are troubleshooting, technical support, and servicing when the machines break down. Timbercut is also working on a new product that only has a preliminary release date which has not yet been announced. The product is an integrated artifact and service called eTimber. It will enable Timbercut to offer remote support to their customers through a 
subscription-based support contract. The long-term plan is that the eTimber platform, including the hardware, will be installed in all new machines that are manufactured.

Mobile Internet coverage has been scarce in the inland areas of northern Sweden. However, this changed during 2009 as a new ISP emerged, delivering a theoretical speed of 3.1 Mbits downlink and 1.8 Mbits uplink in these areas. The eTimber hardware is ready to be connected to the PC in the forestry machines. To be able to use eTimber, the customer needs to sign up for a $3 \mathrm{G}$ mobile Internet service. The $3 \mathrm{G}$ USB modem is then plugged-in to the eTimber hardware. Although the eTimber platform will be installed in all machines, service is not activated until the customer signs up for the subscription-based support contract. Once this is done, the service technician adds the customer's machine(s) to his support system.

\subsubsection{Remote Operation and Digital Training}

In the local area, there are also other types of actors with whom Timbercut, S1, S2, and S3 collaborate. One of these actors is the simulation firm ICT firm 2 (ICT2); another is the research center (TRC). The CEO at S1 provides an account of his role in the start-ups of these firms.

And then, among other things, I got in contact with the Partnership ViceRector at the University and I got involved in starting ICT2. The Vice-Rector and I also started the Research Center. [CEO, S1]

Although ICT2 received some help from Timbercut and S1, S2, and S3 in its startup phase, it is today an established firm with customers outside the forestry industry as well. Reflecting on ICT2's activities with the forestry actors so far, the CEO stresses one area where he would like to see more work get done.

I have thought that we should have done more with the simulation, including this idea of automated systems. I mean, not autonomous vehicles, but remote operation, where you sit in a different location than the vehicle when driving it. We have done such a project with a port cranes manufacturer. We have tried in a simulated environment, where the operator has moved out of the cabin and sits in a control room and runs the vehicles through the monitors. [CEO/ICT2]

The CEO stresses that their simulation gives an opportunity to evaluate if the operator can perform equally well, even though he does not sit inside the vehicle. TRC has performed activities with Timbercut, S1, S2, and ICT2, and has been working with Timbercut on a project with autonomous forestry machines, where the vehicle is programmed to be able to drive itself and detect and avoid obstacles. However, the research manager at TRC expresses some disappointment.

I've felt that the interest from Timbercut has been rather lukewarm almost from the very start...I think it's interesting in terms of research, but it is far ahead of the time when they can really translate it to anything. So...they have provided access to the machines, and made it possible to run it on the field and do tests on the machines. And it's not a bad thing for the research team to have access to such an experimental platform. But really, you also want them to be pushing things forward. [Research manager/TRC] 
One of the projects that TRC has been working on is a remotely operated harvester machine. It is operated from two manned forwarding machines. However, the research manager's view is that Timbercut does not seem to be ready for the project yet. He explains these are such high risk investments that Timbercut chooses to rather wait and monitor their competitors' moves before going ahead with such a product.

Another actor located in the area, which has had discussions with Timbercut, is ICT1. The firm started out serving mainly as a product supplying unit, designing and producing hardware for remote monitoring and communication. Today, the firm focuses on product development in a wider sense through selling software and services. ICT1 has taken on a number of Swedish industrial companies, helping them with the transition from selling products to selling services. This has mostly been done trough installing their sensors which allows, for example, an elevator to order a service technician automatically when needed.

\section{Discussion}

This paper has focused on the ways in which ICTs enable the establishment of open innovation systems in the forestry industry. The digital capabilities embedded in forestry machines have rapidly changed forestry. The move from forestry machines to sociotechnical hybrids has opened up possibilities for changes in industry structure, partnership relations, and business models.

In this paper, we have presented an argument for the utility of the concept of open innovation in the forestry industry. In particular, we have examined how ICTs can enable open innovation practices in the forestry industry. The contribution of this work is two-fold.

First, it initiates discussion about the possibility of innovation at a level that transcends and encompasses the firm level. Indeed, we have argued that ICT innovation will eventually be better understood when it can be placed in an open innovation context. Clearly, as our case illustrates, ICTs have become increasingly critical in the daily work in the forestry industry. However, the digitally enabled forestry machine can also serve as a means by which organizations can tap into and make use of the knowledge embedded in an open innovation system. Organizations and clusters of organizations can achieve long-term competitive advantage by developing and deploying core capabilities which in turn requires developing an overarching strategic intent and core values (see Tushman and O'Reilly 2006). Having said this, the possibilities for such capability-building efforts in forestry must be approached by focusing on what the barriers are for establishing an open innovation system in forestry, and how the use of ICTs could help to enable such open innovation systems. As we have seen, establishing an open innovation system in forestry involves a long journey for some of the actors involved. Our case study tells the story of the traditional value chain in the forestry industry, and in order to identify the barriers for establishing an open innovation system, we need to understand the traditional value chain that has long dominated the forestry industry.

The salient value chain is the one where the raw material-trees in a forest-are refined to paper products through passing a number of links. The first link in the chain consists of forest owning firms and private forest owners that decide to sell a certain 
amount of trees on their grounds. They purchase the services of the logging contractors in the next link. The logging contractors cut down the trees and branches are taken away. The trees are turned into timber and are transported to a landing point. Carriers, which constitute the next link in the value chain, pick up the timber and transport it to a saw or pulp mill. The timber is turned into planks or paper. The mills pass on the finished product to resellers in different industries.

The process illustrates how the product to be passes through the activities in the value chain in a certain order. The product gains value at every activity, a way of doing business that indicates a traditional way of creating value. It is also clear that forestry machine manufacturers are not an actual link in this value chain. Their role is that of a supplier to the first two links in the chain-the forest owners and the logging contractors on which we have chosen to focus. This way of doing business and the industry culture that is likely to come with it is in itself an important barrier to overcome in order to be able to work in an open innovation system where forestry machine manufacturers and ICT specialists take an active and leading role.

There was thus a limited amount of cooperation between the links in the chain other than those directly connected. The innovation that took place in the chain is likely to be closed to influence from actors other than the previous and the next link in the chain, if open to any actor at all. The open innovation ideal was thus far from realized.

Second, we promote the understanding of digitally enabled forestry machines as hybrids. To this end, we build on the materiality discourse in information systems, specifically addressing how technological agency plays a part in the open innovation processes and outcomes. Indeed, while the open innovation literature is largely silent on the role of ICTs in open innovation environments, IS researchers have recently started to conceptualize how ICTs influence work practices (Jonsson et al. 2008; Leonardi 2007; Pollock et al. 2009).

The way that Timbercut and its mechanical suppliers S1 and S2 collaborate today in some respects illustrates an open approach to innovation. However, the actors actively taking part in the actual logging process are not organized according to a traditional value chain only; they are also committed to a closed innovation paradigm.

We found that Timbercut is aligned with the traditional value chain, acting as a supplier to forest owners and logging contractors, listening to their needs and turning these needs into better products. At the same time, we provided an account for how new types of actors, focusing on ICT services and solutions, have emerged and started to participate in forestry projects. However, ICT2 as well as TRC expressed disappointment with the lack of commitment from Timbercut in pushing those projects.

We argue that the way in which Timbercut is embedded in a peripheral position in the current value chain constrains their possibility of fully capturing value from the technology in their forestry machines. Although an open approach to innovation is found in the design and manufacturing of the mechanical technology, to some extent it is the use of this mechanical technology that contributes in holding the traditional value chain together. A possibility for overcoming Timbercut's peripheral position in the current value chain is making an effort to employ an open innovation approach to working with the ICT components of the forestry machines.

With Timbercut's new service, eTimber, their forestry machines not only store data valuable in analyzing the usage, but are also connected to the Internet. Apart from the 
possibility of remote support, there are arguably other latent potentials in a digitally enabled forestry machine connected to the Internet. The access to stored data and the fact that the machine is online holds the potential to enable knowledge sharing between the actors that was not possible previously.

Following Chesbrough and Rosenbloom (2002), if Timbercut wants to fully capture the value in their digitally enabled forestry machines, there are two alternatives: incorporating the technology in their current business or setting up new ventures. The projects with ICT2 and TRC are examples of their work on new technologies together with new types of actors. However, in order to exploit that new technology and eventually translate it into new product offerings, Timbercut may consider setting up a venture with ICT1. In order to capture value in a open innovation system, new types of value constellations can be set up around Timbercut. One option is for Timbercut and ICT1 to invite customers to discuss, assess, and address their needs. A wider definition of the customer in this context could include other actors in the value chain, such as saw and pulp mills. For Timbercut to set up a venture with ICT1 would demand a high degree of openness in terms of access to data and an opening up the protocol of the ICT component in the machines. Another actor that could participate in such interorganizational knowledge sharing is Alpha, providing that they are willing to open up some parts of their system, mapleweb. This would also enable Timbercut and ICT1 to be able to determine how to design and integrate new services. Access to data from the harvester and forwarder that Northlog uses may serve the same purpose.

\section{Conclusions}

This study has addressed the following research question: How can the use of ICT enable the establishment of open innovation systems in the forestry industry?

In order to answer this question, we conducted a case study including key actors from the forestry industry in the northern part of Sweden.

The case study shows how the forestry industry as a whole is dominated by the salient traditional value chain where the raw materials are refined to paper products and that many of the actors are committed to a closed innovation paradigm. We argue that the forestry industry in northern Sweden is currently organized in a very traditional manner, in the value chain arrangement that has characterized business relations in the forestry industry for decades. This way of doing business reveals what we refer to as a traditional way of thinking about value creation, and a limited capability to see beyond the existing value chain.

The barriers identified to working in an open innovation system are hampering the evolution of the forestry industry. It should be noted that informed use of ICTs can be an aid in overcoming them. We argue that the ICT component in Timbercut's forestry machines constitutes a latent potential that can be fully captured through a joint venture with ICT1. Further, we argue that a favorable way of doing this is through the creation of an open innovation system. ICT can enable this transition through the interorganizational knowledge sharing that it makes possible. 


\section{References}

Boudreau, M.-C., Robey, D.: Enacting Integrated Information Technology: A Human Agency Perspective. Organization Science 16(1), 3-18 (2005)

Chesbrough, C.: Open Innovation: A New Paradigm for Understanding Industrial Innovation. In: Chesbrough, H.W., Vanhaverbeke, W., West, J. (eds.) Open Innovation: Researching a New Paradigm, pp. 1-12. Oxford University Press, Oxford (2006)

Chesbrough, C., Rosenbloom, R.S.: The Role of the Business Model in Capturing Value from Innovation: Evidence from Xerox Corporations Technology Spinoff Companies. Industrial and Corporate Change 11(3), 529-555 (2002)

Flyvbjerg, B.: Five Misunderstandings about Case-Study Research. Qualitative Inquiry 12(2), 219-245 (2006)

Fredberg, T., Elmquist, M., Ollila, S.: Managing Open Innovation-Present Findings and Future Directions. Vinnova, Stockholm (2008)

Holmström, J.: Theorizing in IS Research: What Came Before and What Comes Next? Information Resources Management Journal 17(1), 167-174 (2005)

Holmström, J., Boudreau, M.-C.: Communicating and Coordinating: Occasions for Information Technology in Loosely Coupled Organizations. Information Resources Management Journal 19(4), 23-38 (2006)

Holmström, J., Wiberg, M., Lund, A.: Industrial Informatics: Design, Use and Innovation. IGI Global, Hershey (2010)

Jonsson, K., Holmström, J., Lyytinen, K.: Turn to the Material: Remote Diagnostics Systems and New Forms of Boundary-Spanning. Information and Organization 9(4), 233-252 (2009)

Jonsson, K., Westergren, U., Holmström, J.: Technologies for Value Creation: An Exploration of the Remote Diagnostics Challenge in Ubiquitous Computing Environments. Information Systems Journal 18(3), 227-245 (2008)

Leonardi, P.M.: Activating the Informational Capabilities of Information Technology for Organizational Change. Organization Science 18(5), 813-831 (2007)

Leonardi, P.M.: Crossing the Implementation Line: The Mutual Constitution of Technology and Organizing Across Development and Use Activities. Communication Theory 19(3), 278-310 (2009)

Leonardi, P.M., Barley, S.R.: What's Under Construction Here? Social Action, Materiality, and Power in Constructivist Studies of Technology and Organizing. The Academy of Management Annals 4, 1-51 (2010)

Orlikowski, W.J.: Sociomaterial practices: Exploring Technology at Work. Organization Studies 28, 1435-1448 (2007)

Orlikowski, W.J., Iacono, C.S.: Research Commentary: Desperately Seeking the "IT" in IT Research-A Call to Theorizing the IT Artifact. Information Systems Research 12(2), 121-134 (2001)

Orlikowski, W.J., Scott, S.V.: Sociomateriality: Challenging the Separation of Technology, Work and Organization. Academy of Management Annals 2(1), 433-474 (2008)

Pollock, N., Williams, R., Grimm, C., D'Adderio, L.: Post Local Forms of Repair: The Case of Virtualised Technical Support. Social Science Research Network, working paper series (2009)

Rolland, K.H., Monteiro, E.: Balancing the Local and the Global in Infrastructural Information Systems. The Information Society 18(2), 87-100 (2002)

Truex, D., Holmström, J., Keil, M.: Theorizing in Information Systems Research: A Confessional Tale of the Adaptation of Escalation Theory to Information Systems Research. Journal of the Association of Information Systems 7(12), 797-821 (2006) 
Tushman, M.L., O’Reilly, C.M.: Managing Evolutionary and Revolutionary Change. In: Mayle, D. (ed.) Managing Innovation and Change. Oxford University Press, Oxford

Vaast, E., Walsham, G.: Trans-Situated Learning: Supporting a Network of Practice with an Information Infrastructure. Information Systems Research 20(4), 547-564 (2009)

Vanhaverbeke, W.: The Interorganizational Context of Open Innovation. In: Chesbrough, H.W., Vanhaverbeke, W., West, J. (eds.) Open Innovation: Researching a New Paradigm, pp. 205-219. Oxford University Press, Oxford (2006)

Vanhaverbeke, W., Cloodt, M.: Open Innovation in Value Networks. In: Chesbrough, H.W., Vanhaverbeke, W., West, J. (eds.) Open Innovation: Researching a New Paradigm, pp. 220-240. Oxford University Press, Oxford (2006)

Walsham, G.: Interpretive Case Studies in IS Research: Nature and Method. European Journal of Information Systems 4, 74-81 (1995)

Westergren, U., Holmström, J.: Outsourcing as Open Innovation: Exploring Preconditions for the Open Innovation Model in the Process Industry. In: Proceedings of 29th ICIS, Paris, France (2008)

Yin, R.: Case Study Research: Design and Methods, 3rd edn. Sage Publications, Thousand Oaks (2003)

Zammuto, R.F., Griffith, T.L., Majchrzak, A., Dougherty, D.J., Faraj, S.: Information Technology and the Changing Fabric of Organization. Organization Science 18(5), 749-762 (2007)

Zuboff, Z.: In the Age of the Smart Machine: The Future of Work and Power. Basic Books, New York (1988)

\section{About the Authors}

Daniel Nylén is a Ph.D. student at the Department of Informatics, Umeå University. His research examines the digitalization of a number of contexts and industries. A particular focus is investigating emerging digital innovation processes in the media industry.

Jonny Holmström is a professor of Informatics at Umeå University, Sweden. His research interests include the organizational consequences of information technology, digital innovation, and open innovation methods for university-industry collaboration. Holmström's larger research program has examined how organizations innovate with IT, and he is currently investigating how organizations in the process industry sector can develop sustainable competitive advantages through mindful use of IT, and how media organizations make use of a heterogeneous media portfolio. His research has been published in Communications of the AIS, European Journal of Information Systems, Information and Organization, Information Resources Management Journal, Information Technology and People, International Journal of Actor-Network Theory, Technological Innovation, International Journal of Systems Assurance Engineering and Management, Journal of Information Technology Management, Journal of the AIS, Journal of Global Information Technology Management, and Scandinavian Journal of Information Systems. 


\section{Appendix: Description of the Actors Included in the Study}

\begin{tabular}{|c|c|c|}
\hline Organization & Description & Role \\
\hline $\begin{array}{l}\text { Logging } \\
\text { contractor } \\
\text { (Northlog) }\end{array}$ & $\begin{array}{l}\text { Logging contractor firm. Our informant owns and } \\
\text { manages the firm. Northlog has three employees. } \\
\text { Including the contractor, the total of four persons } \\
\text { work shifts on one harvester machine and one for- } \\
\text { warder machine. Northlog currently has a 5-year } \\
\text { contract with one of Sweden's largest forest owners. }\end{array}$ & Owner \\
\hline $\begin{array}{l}\text { Forest owning } \\
\text { company } \\
\text { (Alpha) }\end{array}$ & $\begin{array}{l}\text { One of the largest forest owners in Sweden. The firm } \\
\text { manages its own forest through logging and selling } \\
\text { timber to sawmills and pulp mills. Alpha also } \\
\text { acquires timber from private land owners. The firm } \\
\text { has over } 700 \text { employees. }\end{array}$ & $\begin{array}{l}\text { Purchaser } \\
\text { Logging } \\
\text { manager } \\
\text { (TLM) } \\
\text { R\&D manager }\end{array}$ \\
\hline $\begin{array}{l}\text { Forestry } \\
\text { machines } \\
\text { manufacturer } 1 \\
\text { (Timbercut) }\end{array}$ & $\begin{array}{l}\text { Founded in the } 1960 \text { s as a local firm, developing and } \\
\text { manufacturing forestry machines. Since then, a } \\
\text { number of changes in ownership also resulted in a } \\
\text { number of name changes. Timbercut is today a divi- } \\
\text { sion within a multinational enterprise. The firm is } \\
\text { today one of the worlds largest manufacturers of } \\
\text { forestry machines. The headquarters are still located } \\
\text { in the northern Swedish town were the original firm } \\
\text { was founded in the } 1960 \text { s. }\end{array}$ & $\begin{array}{l}\text { Product } \\
\text { manager } \\
(\mathrm{TPM})\end{array}$ \\
\hline $\begin{array}{l}\text { Forestry } \\
\text { machines } \\
\text { manufacturer } 2\end{array}$ & $\begin{array}{l}\text { Recently started manufacturer of smaller forestry } \\
\text { machines }\end{array}$ & CEO \\
\hline Supplier 1 (S1) & Produces components to forestry machines. & Chairman \\
\hline Supplier 1 (S2) & Produces components to forestry machines. & CEO \\
\hline Supplier 1 (S3) & Produces components to forestry machines. & CEO \\
\hline $\begin{array}{l}\text { Research center } \\
\text { (TRC) }\end{array}$ & $\begin{array}{l}\text { Conducts research on intelligent off-road vehicles. } \\
\text { More specifically on autonomous forestry machines. }\end{array}$ & $\begin{array}{l}\text { Research } \\
\text { manager }\end{array}$ \\
\hline ICT1 & $\begin{array}{l}\text { The firm started out serving mainly as a product sup- } \\
\text { plying unit, designing and producing hardware for } \\
\text { remote monitoring and communication. Today, the } \\
\text { firm focuses on Product Development in a wider } \\
\text { sense through selling software and services. }\end{array}$ & CEO \\
\hline ICT2 & $\begin{array}{l}\text { Formed in the late } 1990 \mathrm{~s} \text { as a spin-off from the } \\
\text { University. Produces training simulators for forestry } \\
\text { machines. The firm is co-owned by Timbercut, but } \\
\text { has a row of other multinational customers. End- } \\
\text { customers are either training organizations or fleet } \\
\text { owners. }\end{array}$ & CEO \\
\hline Municipality & $\begin{array}{l}\text { Local municipality of a small town where some of the } \\
\text { suppliers are located. }\end{array}$ & $\begin{array}{l}\text { Trade and } \\
\text { industry } \\
\text { director }\end{array}$ \\
\hline
\end{tabular}

